\title{
Generational Approach to Factors Influencing Career Choice in
} Accounting*

Jony Hsiao

Universidade de São Paulo, Faculdade de Economia, Administração e Contabilidade, Departamento de Contabilidade e Atuária, São Paulo, SP, Brazil.

Silvia Pereira de Castro Casa Nova

Universidade de São Paulo; Faculdade de Economia, Administração e Contabilidade, Departamento de Contabilidade e Atuária, São Paulo, SP, Brazil.

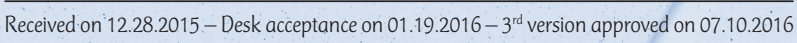

\section{ABSTRACT}

This research aims to grasp which factors influence the generation $Y$ to choose accounting as its career. A significant decline in the number of candidates willing to pursue a career as accountant has been observed abroad - USA, Australia, and Japan. However, in other countries - Brazil, Singapore, and Hong Kong - the opposite has been observed. Another issue is the decline in educational qualification of those pursuing an accounting career, contributing in a way that many talented students change their career choice. This may be explained by the fact that people tend to believe accounting is an exact science, full of calculations, boring, and not very creative, bringing an unbalance between the traits an individual should have according to the job market and those perceived by society. In order to give a contribution to literature concerning the factors that influence the generation $\mathrm{Y}$ in its career choice, a goal of this research was conducting an exploratory study where some hypotheses were formulated to support the discussion. We used Mannheim's Generational Theory and the literature on career choice. Data collection was carried out using a questionnaire, based on Schwartz's Portrait Value Questionnaire and Germeijs and Verschueren's Student Choice Task Inventory, adapted through focus group interview. Data were fully collected online and the sample consisted of 665 subjects. The results showed that people who chose accounting as their career were influenced by factors such as creativity, independence, challenging and dynamic environment, job security, money-making, job availability, and other significant people - friends and teachers. The subjects were not influenced by social factors, such as working with people and making contributions to society and family. They wish for more autonomy, creativity, and flexibility at work, and people still care about job security and money-making.

Keywords: accounting, profession, career, generation Y, social influence.

*Paper presented at the XV USP Congress of Controllership and Accounting, São Paulo, SP, Brazil, July 2015. 
I believe that procrastination is perhaps a characteristic of the generation I belong to and this fact doesn't have to be seen as something negative. I believe that I am, like most of my friends, more interested in enjoying the walk than arriving at somewhere pre-established. And along this walk we lose ourselves and find ourselves, without knowing for sure where to go, but with the certainty and desire to just enjoy the walk.

(Fernando Crepaldi, sophomore in Accounting at the Faculdade de Economia, Administração e Contabilidade of the Universidade de São Paulo - 2012)

\section{INTRODUCTION}

Increased school time and increased years of schooling, named by Pimenta (2007) as "post-adolescence," are observed not only due to increased length in time, but also because of its association with other factors, such as a later entry into the job market, since young individuals wait and try out professions, remain with their family, and delay marriage. Such an increased length of schooling may be explained by the characteristics of modern society, with sudden social and capitalist changes: people believe that a young adult is never prepared for a professional career, she/he is expected to acquire further knowledge and expertise (Oliveira \& Melo-Silva, 2010).

This new generation - the Gen Y (Eisner, 2005) -, which has been entering the job market in recent years, shows some traits that make it different from previous generations. The Gen Y (Stein, 2013) consists of young people who are eager to consume new technologies, looking for immediate outcomes and rewards, yearn for autonomy and balance between personal life and work, prone to multitasking, settled down to a domestic life and civic duties, although there are controversies concerning these traits in the literature, e.g. Dejoux and Wechtler (2011), who present myths related to the Gen Y, such as lower efficiency due to a predilection for multitasking.

The international academic research in accounting that addresses the theme of generations is at an advanced stage. Authors like Ahmed, Alam, and Alam (1997), Albrecht and Sack (2000), Auyeung and Sands (1997), Chen, Jones, and McIntyre (2008), Lindquist (2008), Mauldin, Crain, and Mounce (2000), Milliron (2008), Sugahara, Boland, and Cilloni (2008), and Tan and Laswad (2006) are concerned with issues as attracting, recruiting, selecting, training, and retaining these young people in the organizations. In Brazil, research addressing this theme has gained ground recently through studies conducted by authors like Cavazotte, Lemos, and Viana (2012), Oliveira, Piccinini, and Bitencourt (2012), Scharf, Rosa, and Oliveira (2012), and Vasconcelos, Merhi, Goulart, and Silva (2010).

Some studies try to grasp which factors are more important so that students choose the accounting career, since there is a concern in the academic community regarding the lower educational qualification of students in this field (Chen et al., 2008; Sugahara et al., 2008; Sugahara, Kurihara, \& Boland, 2006). Also, the number of students attending Higher Education has increased. Thus, the number of individuals who pursue an accounting career (Ahmed et al., 1997; Chen et al., 2008; Danziger \& Eden, 2006; Mauldin et al., 2000; Sugahara et al., 2006, 2008; Tan \& Laswad, 2006) is a matter of concern.

The profession and professional image seem to be contributing factors for those who did not choose to pursue an accounting career. Chen et al. (2008) point out, in a study conducted with Australian students, that those who chose to pursue an accounting career after some contact with it during High School saw more benefits than drawbacks with this option, but the experience did not influence their decision.

Data from this study indicate that market factors seem to be relevant in the decision to pursue an accounting career. Other factors, such as the intrinsic ones, did not seem to influence the decision.

The fact that profession and professional image do not contribute so that people choose to pursue an accounting career may derive from the students' perception that such a career is boring and it has lower wages than other businessrelated areas, as pointed out by Azevedo (2010) concerning accountants' stereotypes.

The literature addresses the career choice process, as well as the factors that influence it (e.g. Barreto \& Aiello-Vaisberg, 2007; Nepomuceno \& Witter, 2010; Ojeda, Creutzberg, Feoli, Melo, \& Corbellini, 2009). In this regard, some instruments were developed to evaluate career choice, such as the "Study Choice Task Inventory" (SCTI) (Germeijs \& Verschueren, 2006), "Career Maturity Inventory," "Career Development Inventory," and "My Vocational Situation Scale," used by Hirschi and Läge (2007), and the "Career Decision Difficulties Questionnaire" (Gati, Krausz, \& Osipow, 1996). These authors aim to determine which factors lead students to pursue a career in accounting, since the decline in educational qualification of accountants is a matter of concern (Chen et al., 2008; Sugahara et al., 2006, 2008).

Ahmed et al. (1997), in a study on the factors that influence students to pursue an accounting career choice, 
grouped 19 items into 5 factors: (i) intrinsic reward, (ii) good starting salaries, (iii) good long-term salaries, (iv) job availability, and (v) experience with accounting during High School. This study tested intrinsic factors, such as satisfaction, autonomy, creativity, and dynamic environment; financial and market factors, such as job availability, job security, career progression, flexibility, and outcomes and rewards; and aspects related to benefits and drawbacks, such as challenges during the first year working as an accountant, chance to become a CEO, difficulty of qualification, less leisure time, lower salaries during the early years, and negative image of accountants. Influence of parents and friends, prior contact with accounting, and Higher Education in accounting were also considered.

The results showed that only financial and market factors were significant, they were associated with students' decision to pursue an accounting career; those who had already chosen it realized that the benefits are greater than the drawbacks, while those who had not chosen it regarded the profession as boring.

Therefore, considering (1) that the Gen $\mathrm{Y}$ is going to take management positions in organizations in the upcoming years, (2) the increasing demand for highly qualified professionals to meet the needs of new business models, and (3) the decreased number of students and professionals who can meet the market needs, this article aims to identify and discuss the factors that influence the Gen Y to pursue an accounting career, so that skilled individuals can be attracted and retained both by the academy and the job market.

\section{CAPITALISM AND THE SPIRIT OF CAPITALISM}

The concept of capitalism has been developed over centuries. Gras (1942) suggests that this concept exists for about 170 years, but the system has been known long before this. The author works with five views on capitalism: (i) technological concept - machinery and capital to produce goods and services, (ii) ethical concept of socialism and communism - capitalism as a way to exploit the worker, (iii) capitalism as private equity - capitalism contrary to common property, (iv) production system where capital prevails - capital as the predominant form in the system, and (v) capital management system - whose primary purpose is the production and accumulation of surplus value. These ideas are not complete per se, we can notice the evolution of the term because the system has adapted to a new social dynamics.

Boltanski and Chiapello (2009) characterize and define the capitalism as the accumulation of capital through profit extraction, which is reinvested to generate more profit, thus it enables continued capital increase and accumulation. This constant transformation of capital into cash and turning the latter into further investment leads to enrichment, which derives from the balance difference between two periods.

Capitalism is based on two main players: the big capitalist, who holds the means of production, and the little capitalist, who is subject to the first one. According to this rationale, players should be encouraged to engage in this capitalaccumulating process and keep it going on. This motive is named as the spirit of capitalism (Boltanski \& Chiapello, 2009).

The ideology that grounds, justifies, and encourages individuals to engage in capitalist activities leads them to commit to organizations, usually due to individual motives. The latter may have various origins: religious, social, and professional, shaping identity, cultural, and economic aspects.
In short, the spirit of capitalism is "a set of beliefs related to the capitalist order that contributes to justify and sustain this order, legitimizing modes of action and the provisions consistent to it" (Boltanski \& Chiapello, 2009).

Without this ideology to support and keep engagement, perhaps capitalism would not persist until today. This spirit changes, adapting to new economic and social environments, as well as to new business models and management practices.

Boltanski and Chiapello (2009) identify two previous stages of the spirit of capitalism. The first stage took place in the late $19^{\text {th }}$ century. The characteristics justifying the engagement of employers and employees consisted in elements that provided them with safety in the system, economic aspects that improved everyday life, and tradition, with an emphasis on family and paternalistic values reflected on the relations between employers and employees. The second stage occurred between 1930 and 1960. It was characterized by capital accumulation induced by mass production, economics of scale, standardization of products, and massification of consumption (Boltanski \& Chiapello, 2009). In this mode of capitalism, guarantees and benefits for employees who hold Higher Education certificates are paths to decision-making and leadership positions, in addition to meeting their biggest goals.

Currently, a third phase of modernity, named as hypermodernity, may be defined as "a liberal society characterized by movement, fluidity, flexibility; indifferent like never before to the great structuring principles of modernity, that needs to adapt to the hypermodernity rhythm to not disappear" (Lipovetsky, 2011, p. 26).

Boltanski and Chiapello (2009) characterize the new spirit of the capitalism, where networking formation and proliferation are valued. A world formed by connections meets the needs pointed out by the capitalist critics: freedom, 
creativity, and autonomy in the workplace (flexible working hours, decision-making approach, personality-driven work). The new spirit of capitalism does not aim to sell only products, but also feelings (Hickel \& Khan, 2012).
A new configuration of the job market provided workers with less guarantees in exchange of autonomy, flexibility, and creativity.

\section{GENERATIONS}

The concept of generations has been an issue, despite the efforts to reach a consensus in the 1960s and 1970s. This concept has been applied since antiquity to explain social change processes (Laufer \& Bengston, 1974).

Mannheim (1952) points out two approaches: positivist and historical-romantic. The first approach aims to grasp the concept and define how older generations begin to fade and get replaced by the next generations. This view is associated with the biological growth rate. Improvement and social changes may be determined by the individuals' lifetime. The second approach depicts generational change not as a linear process, but in relation to a particular period, which cannot be measured on a quantitative basis, it can only be qualitatively experienced. Thus, regarding generation as a time-based unit in terms of intellectual history, we may rule out measurement units such as hours, minutes, days, years, etc. This allows us to address intellectual movements.

A first concept Mannheim (1952) uses to analyze the issues of generation is that of actual group with specific interrelations between individuals. Also, belonging to a certain generation or age group leads people to share the same space in the historic and social process, determining a range of experiences, characteristics, and ways of thinking, feeling, and behaving. Wilhelm Pinder, cited by Mannheim (1952), introduced the concept of entelechy, which is another way of experiencing life and the world, a term coined by Aristotle to describe reality as fully realized, something opposed to potentiality (Mirador International, 1977).

In order to better define and conceptualize generations, Mannheim (1952) introduced the concept of actual generation and generational unit. Actual generation exists when individuals from a generational community form concrete bonds and they are exposed to the same dynamic social, intellectual, and historical processes in an environmental change context (Mannheim, 1952). Generational unit consists in variations within a cohort (Bengtson, Furlong, \& Laufer, 1983). Similar thinking characterizes its members as a group (Mannheim, 1952). Laufer and Bengtson (1974) point out the generational units respond to the same issues according to their experience with regard to the impacts of social change.

The generational units represent a much more concrete bond than the actual generation as such. Youth experiencing the same concrete historical problems may be said to be part of the same actual generation; while those groups within the same actual generation which work up the material of their common experiences in different specific ways constitute separate generation units (Mannheim, 1952, p. 304).

\section{CAREER CHOICE}

Career choice is a process rather than a specific event in a teenager's life. Barreto and Aiello-Vaisberg (2007), Gati and Saka (2001), and Nepomuceno and Witter (2010) point out that career choice is a major decision in a person's life, it usually takes place during adolescence, and this may bring serious consequences later in life, regarding fortune, lifestyle, and education, as well as personal and professional acquaintanceships.

Germeijs and Verschueren (2006) highlight that the career choice process is complex and, when it is not optimized, this can lead to increased risk of course dropout and evasion in Higher Education.

Career choice is a major transition for teenagers, which involves family influence and social pressure. Choosing a profession is related to personal and occupational identity
(Dubar, 2005), worldview, and further decisions; it is regarded as a time of inner conflicts and anxieties mainly reflected on the family environment (Santos, 2005).

According to Erikson, Almeida, and Pinho (2008), tackling the identity crisis is a major issue for teenagers, the time to develop a project for adult life. A teenager has to make decisions and this implies giving up other options (Almeida \& Pinho, 2008; Santos, 2005).

Oliveira and Melo-Silva (2010) address the issue of career choice from the perspective of economic and cultural variables, supported by Bourdieu's Theory of Cultural Reproduction, discussing work-related symbolic violence.

Family may facilitate or complicate this process. Directly or indirectly, family expectations are reflected on students, as parents chase lost dreams by trying to make their children 
succeed, turning the career choice process into cultural reproduction (Almeida \& Pinho, 2008; Nepomuceno \& Witter, 2010; Ojeda et al., 2009).

Pereira and Garcia (2007) argue that friends have been regarded as a source of emotional support in the career choice process, while family provides instrumental support. Teenagers pointed out a significant participation of friends in professional choice, but a low perception of their influence in decision-making.
The literature review provides an overall perception of the economic and social context where career choice takes place. The capitalist system and its ideology have changed over time and the various generations and generational units perceive and experience changes differently. The career choice process is also discussed concerning the factors that influence it, such as family, friends, education background, and socialization.

\section{METHODOLOGY}

The sample for this study consisted of High School students who attended the $6^{\text {th }}$ USP Careers Fair, held on August 2 to 4,2012. This event was promoted and organized by the USP's Office of the Provost for Culture and University Outreach (PRCEU), which provides the university and society with means of communication and relationship. The USP Careers Fair aims to promote activities for students, in which families and teachers also participate, helping them to choose a career. The event offers vocational counseling, informal group meetings with teachers from various fields of knowledge, a tour around the university campus, and a Physics Show, where experiments are presented.

\subsection{Sample Description}

The students and/or schools interested in participating in the USP Careers Fair needed to preregister. Thus, a student who wanted to participate could either register individually or along with the school, becoming eligible for the event. The database of participants was accessed under permission of the PRCEU.

Out of the 10,580 individuals registered in the database, 9,303 were invited for this study. This is justified by the fact that many participants did not provide an email address or they provided an invalid email address or duplicated information.

Thus, we resorted to a non-probabilistic sample. It may be classified as a convenience sample, because respondents were gathered from a specific group of High School students: those who attended the USP Careers Fair. Therefore, our results cannot be generalized to the whole population, because convenience samples may have the so-called selection bias, i.e. participants' characteristics can differ from those of the target population as a whole.

Through the literature review and three focus groups conducted with High School students, young people pursuing business careers, and undergraduate students in biological sciences, exact sciences, and business administration -, six hypotheses were formulated and tested: a) H1: Individuals from the Gen Y see family as a social institution that exerts less influence on those who choose to pursue an accounting career.

b) H2: Intrinsic factors of the accounting practice, such as creativity, autonomy, and challenging and dynamic environment, are believed to exert less influence on those who choose to pursue an accounting career.

c) H3: Extrinsic factors, such as job security, moneymaking, and job availability, exert more influence on those from the Gen $Y$ who choose to pursue an accounting career.

d) H4: Individuals from the Gen Y see Other Significant People - friends and teachers - as non-influential on the decision to pursue an accounting career.

e) H5: Individuals from the Gen Y do not see accounting as a prestigious career, therefore, this is not an influential factor for those who choose to pursue an accounting career.

f) H6: Social factors - working with people, contributing to society - exert less influence on those from the Gen Y who choose to pursue an accounting career.

\subsection{Data Collection and Analysis}

In order to prepare the questionnaire, three focus groups were selected aiming to analyze which of the factors that influence career choice would appear in the respondents' speeches. The literature review on factors influencing the career choice process provided our questionnaire with items. Questions adapted from the SCTI, proposed by Germeijs and Verschueren (2006), were also used. We chose to use the SCTI because this instrument has been validated with regard to its reliability and validity, where six scales provide an acceptable internal consistency (Germeijs \& Verschueren, 2006). The SCTI has been validated with sophomore and senior High School students in Flanders (Belgium) right before entering college/university education, just like the respondents in this study.

The instrument was obtained by contacting the authors through email sent to Veerle, on May 8, 2012. We received the SCTI through email on June 15, 2012, in Dutch. We sent 
a second email message on August 22, 2012, asking for the English version of the SCTI. The following steps were taken to obtain its Portuguese version: (i) the Dutch version was translated into English by a professional translator (T1); (ii) having two English versions as a basis - the questionnaire in Dutch translated into English (V1) and the questionnaire in English provided by Germeijs and Verschueren (2006) (V2) - two independent professional translators (T2 and T3) translated each English version into Portuguese: T2 translated V2 and T3 translated V1.

After receiving the texts translated into Portuguese, both questionnaires were analyzed by the authors of this study, in order to prepare the final version of the questionnaire in Portuguese. Then, it was sent to another independent professional translator (T4), who translated it back into English - this procedure is named as "back-translation."

Data on individual registration were collected through an online survey by using the software SurveyMonkey. An email message providing the link to the survey was created (surveymonkey.com/s/67XHG5Y). The USP's Electronic Computing Center (CCE) was contacted to help us sending these email messages. An email list was created by the CCE (pesqcarreira@listas.usp.br) providing the link to the survey, then the latter was sent to everyone included in the list. The invitations sent to respondents made it clear that participation was voluntary, they could withdraw from the study anytime wished to, and that data would be processed in an aggregate form, with no reference to any particular participant. As a way to encourage participation, a thirdgeneration iPad was raffled off.

Data were collected from December 6 to December 27, 2012. A total of 954 responses were obtained, but only 665 questionnaires were analyzed, because some of them were not complete. Participants' age ranged from 13 to 57 years. Therefore, we chose to include in the sample individuals aged from 16 to 21 years who were completing High School or enrolling in a college admission prep course in 2012. It was not possible to determine non-respondent bias, because no sociodemographic information on the sample with 9,303 individuals was available. The PRCEU allowed access to the email list and the CCE provided the online questionnaire. As a consequence, we cannot assure that respondents differ in any relevant way from the sample. Smith (2012) classifies the lack of response this way: no motivation to complete the survey; and the survey instrument is temporarily "shelved" because of time pressures. Both reasons were tackled in this study by offering a prize. The other reasons listed by Smith (2012) can be considered only with regard to a mail survey, they do not apply to an online survey (e.g. wrong address, unopened letter, recipient unable to understand the message, etc.). Thus, on the one hand, we cannot assure there is no non-response bias; on the other hand, there is no reason to infer that, as claimed by Smith (2012, p. 124), "there are systematic differences between respondents and nonrespondents and such differences will impact findings."

Preliminary analysis showed that the group S1 had 480 women and 185 men. In order to control bias due to gender, the group S2 was created; 185 women were chosen among the 480 women included in the original sample. Selection was conducted through the Microsoft Excel's Randbetween function. Individuals were divided into five categories to facilitate the analysis, having a table of fields of knowledge recognized by the Brazilian Coordination for the Improvement of Higher Education Personnel (CAPES) as a basis. Nine fields of knowledge were distributed as follows:

a) Applied Social Sciences (ASS) - comprises the Applied Social Sciences as defined by the CAPES;

b) Exact Sciences (ES) - comprises Exact Sciences, Earth Sciences, and Engineering;

c) Biological Sciences (BS) - comprises Biology, Health Sciences, and Agricultural Sciences;

d) Human Science (HS) - comprises the Humanities and Linguistics, Language, and Arts;

e) Others $(\mathrm{O})$ - this group consists of careers in other multidisciplinary areas.

The hypotheses include individuals who considered a career in accounting. Since the research results showed that only a few individuals considered such a career, it would not be possible to provide an analysis to infer tendencies. The hypotheses were addressed considering that individuals grouped in the ASS might share the same entelechy (Mannheim, 1952), thus working facts and experiences in a similar way.

Multivariate analysis was conducted using the software SPSS, version 20. The questionnaire was tested in terms of internal consistency, normality, and homoscedasticity to determine which was the best fit to the data.

\subsection{Portrait Value Questionnaire}

For this study, we also used the Portrait Value Questionnaire (PVQ), developed from the Schwarz Value Survey (SVS), by Schwartz and Bardi (2001). PVQ aims to offer a more simple and more concrete instrument to measure the 10 constructs of the universal human values proposed by Schwartz (1994). The instrument was validated in a work by Schwartz, Gila, Lehmann, Burgess, Harris, and Owens (2001) in three studies.

The PVQ was analyzed using suggestions by Schwartz (n.d) to compute scores for the 10 items which constitute the 10 motivational human values. The author argues that this is needed to correct individual differences on the scale 
before conducting the analysis. The steps to be taken are:

a) Compute the score for the 10 values using the average score for the items that comprise each value;

b) Compute the average score for each individual concerning the 21 items of the human values, naming it as mRAT;

c) Compute the central score for the 10 motivational human values using the average score for the items that index each human value where they are centered by subtracting mRAT from the individuals' average scores.

Schwartz (n.d) argues that people differ individually and culturally when a scale is used to measure answers. For instance, two individuals may assign the same relevance to a human value, but some individuals may discriminate more pointedly between their values. Therefore, standardizing answers might lead every variance to vanish.

\section{RESULTS AND DISCUSSION}

\subsection{Portrait Value Questionnaire}

Cronbach's alpha indicates whether a set of items in a test is adequate to assure interpretability concerning individual differences; in a homogeneous test, the items measure the same object with a substantial internal consistency and it is psychologically interpretable (Cronbach, 1951). Cronbach's alpha showed consistency in the PVQ (Table 1).

Table 1 Reliability test-Portrait Value Questionnaire

\begin{tabular}{cccc}
\hline & & Sample 1 & Cronbach's alpha based \\
on standardized tests & Cronbach's alpha & $\begin{array}{c}\text { Items } \\
\text { (n) }\end{array}$ & 21 \\
\cline { 2 - 4 } Total & 0.808 & 0.820 & 21 \\
\hline Applied Social Sciences & 0.797 & 0.810 & 21 \\
\hline Human Science & 0.808 & 0.817 & 21 \\
\hline Exact Sciences & 0.803 & 0.821 & 21 \\
\hline Biological Sciences & 0.840 & 0.847 & 21 \\
\hline Others & 0.755 & 0.767 & 21 \\
\hline Total & & Sample 2 & 21 \\
\hline Applied Social Sciences & 0.799 & 0.812 & 21 \\
\hline Human Science & 0.804 & 0.811 & 21 \\
\hline Exact Sciences & 0.786 & 0.793 & 21 \\
\hline Biological Sciences & 0.778 & 0.802 & 21 \\
\hline Others & 0.859 & 0.868 & 0.815 \\
\hline
\end{tabular}

Source: Prepared by the authors. 
Coefficients range from 0.755 to 0.859 in non-standardized tests and from 0.767 to 0.868 in standardized tests, thus we may conclude there are consistency and homogeneity in the answers.

Kruskal-Wallis test was conducted to evaluate whether $\mathrm{k}$-independent samples $(\mathrm{k}>2)$ come from the same population (Fávero, Belfiore, Silva, \& Chan, 2009). The null hypothesis claims that sample distribution is equal and the alternative hypothesis claims there are differences in sample distribution (Table 2).

Table 2 Kruskal-Wallis test for the 10 motivational values - Portrait Value Questionaire

\begin{tabular}{|c|c|c|c|c|}
\hline \multirow{2}{*}{$\begin{array}{l}\text { Motivational } \\
\text { value }\end{array}$} & \multicolumn{2}{|c|}{ Sample 1} & \multicolumn{2}{|c|}{ Sample 2} \\
\hline & $\chi^{2}$ & $\begin{array}{l}\text { Asymp. } \\
\text { sign. }\end{array}$ & $\chi^{2}$ & $\begin{array}{c}\text { Asymp. } \\
\text { sign. }\end{array}$ \\
\hline Security & 10.333 & 0.035 & 10.541 & 0.032 \\
\hline Conformity & 18.988 & 0.001 & 15.714 & 0.003 \\
\hline Tradition & 7.403 & 0.116 & 8.121 & 0.087 \\
\hline Benevolence & 33.699 & 0.000 & 16.993 & 0.002 \\
\hline Universalism & 31.778 & 0.000 & 18.932 & 0.001 \\
\hline Self-direction & 33.837 & 0.000 & 29.832 & 0.000 \\
\hline Stimulation & 8.419 & 0.077 & 15.417 & 0.004 \\
\hline Hedonism & 4.321 & 0.364 & 5.616 & 0.230 \\
\hline Achievement & 11.091 & 0.026 & 10.064 & 0.039 \\
\hline Power & 20.551 & 0.000 & 11.291 & 0.023 \\
\hline
\end{tabular}

Note. The five groups that comprised this analysis in S1 and S2 were from Applied Social Sciences $(n=235$ and $n=115)$, Human Science $(n=102$ and $n=67)$, Exact Sciences $(n=176$ and $n=116)$, Biological Sciences $(n=120$ and $n=51)$, and Others $(n=32$ and $n=21)$.

Source: Prepared by the authors.

The PVQ - adapted from Schwartz (1994) by Almeida and Sobral (2009) - was used to check generational traits of individuals included in the sample, since value formation during primary socialization (Dubar, 2005), as well as its persistence or discontinuity, defines cultural changes over time, enabling the emergence of new generations and new ways of thinking and acting in society (Bengtson et al., 1983; Laufer \& Bengtson, 1974).

The results indicate for $\mathrm{S} 1$ that only the motivational values of "tradition" $\left(\chi^{2}[4, \mathrm{n}=665]=7.403, p<0.05\right.$, since the test's value is $p=0.116>0.05)$, "stimulation" $\left(\chi^{2}[4, \mathrm{n}\right.$ $=665]=8.419, p<0.05$, since the test's value is $p=0.077$ $>0.05)$, and "hedonism" $\left(\chi^{2}[4, \mathrm{n}=665]=4.321, p<0.05\right.$, since the test's value is $p=0.364>0.05)$ had no differences between the five categories. For S2, only "tradition" ( $\chi^{2}[4$, $\mathrm{n}=370]=8.121, p<0.05$, since the test's value is $p=0.087$ $>0.05)$ and "hedonism" $\left(\chi^{2}[4, \mathrm{n}=370]=5.616, p<0.05\right.$, since the test's value is $p=0.230>0.05)$ had no difference between the categories.

Tradition (conservation value), in the circular structure proposed by Schwartz (1994), is located at the orthogonal dimension conservation vs. openness to change, as well as hedonism and stimulation (openness to change values). The answers both to S1 and S2 indicate that, regarding tradition, the mean score of answers (9-point Likert scale) was around 4.5 and for hedonism and stimulation it was 7.5. In this sample, no difference was found for these three motivational values, indicating there is a tendency for individuals to assign less value to tradition aspects, such as respect, commitment, and acceptance of traditions and ideas derived from the cultural environment, assigning more openness to change ideals, such as search for personal well-being, novelty, and challenges. The results corroborate discussions conducted by Beck and Beck-Gernsheim (2002), Boltanski and Chiapello (2009), and Lipovetsky (2011), concerning individuals and their relation to the capitalist system, where answers to the first and second spirits of capitalism led to changes in the job market, with less job security and workers' guarantees in exchange of more autonomy and flexibility. This scenario involves worse working conditions, requiring workers to adapt to new occupational dynamics and organization, establishing a compulsory individualization process.

The motivational value stimulation showed significant difference in the category S2, which did not occur in S1. This may be due to gender differences (particularly in S1); when S2 was created with the same number of women and men, perhaps the differences were mitigated. 


\subsection{Influence of Family and Peers}

Kruskal-Wallis and Mann Whitney U-tests were conducted for the factors family and peers; the first compared the five groups and the second addressed gender differences. Kolmogorov-Smirnov's test showed non-normality.

Table 3 Kruskal-Wallis and Mann-Whitney - influence of family and peers

\begin{tabular}{|c|c|c|c|c|c|c|}
\hline \multirow{3}{*}{ Factors } & \multicolumn{3}{|c|}{ Sample 1} & \multicolumn{3}{|c|}{ Sample 2} \\
\hline & \multicolumn{3}{|c|}{ Kruskal-Wallis } & \multicolumn{3}{|c|}{ Kruskal-Wallis } \\
\hline & $\chi^{2}$ & df & Asymp. sign. & $\chi^{2}$ & df & Asymp. sign. \\
\hline Friend & 9.146 & 4 & 0.058 & 3.159 & 4 & 0.532 \\
\hline Teacher & 9.002 & 4 & 0.061 & 4.92 & 4 & 0.296 \\
\hline Mother & 9.572 & 4 & 0.048 & 8.056 & 4 & 0.090 \\
\hline Father & 8.271 & 4 & 0.082 & 4.157 & 4 & 0.385 \\
\hline \multirow[t]{3}{*}{ Family } & 4.240 & 4 & 0.375 & 3.122 & 4 & 0.538 \\
\hline & \multicolumn{3}{|c|}{ Mann-Whitney } & \multicolumn{3}{|c|}{ Mann-Whitney } \\
\hline & Mann-Whitney U & \multicolumn{2}{|c|}{$\begin{array}{l}\text { Asymp. sign. } \\
\text { (2-tailed) }\end{array}$} & Mann-Whitney U & \multicolumn{2}{|r|}{$\begin{array}{l}\text { Asymp. sign. } \\
\text { (2-tailed) }\end{array}$} \\
\hline Friend & $38,901,000$ & \multicolumn{2}{|c|}{0.013} & $15,047,500$ & \multicolumn{2}{|r|}{0.044} \\
\hline Teacher & $40,070,500$ & \multicolumn{2}{|c|}{0.051} & $14,739,000$ & \multicolumn{2}{|r|}{0.021} \\
\hline Mother & $40,003,000$ & \multicolumn{2}{|c|}{0.047} & $14,639,500$ & \multicolumn{2}{|r|}{0.016} \\
\hline Father & $42,739,500$ & \multicolumn{2}{|c|}{0.454} & $17,090,000$ & \multicolumn{2}{|r|}{0.983} \\
\hline Family & $38,428,000$ & \multicolumn{2}{|c|}{0.007} & $14,244,500$ & \multicolumn{2}{|r|}{0.005} \\
\hline
\end{tabular}

Source: Prepared by the authors.

The results indicated that the factors "father" and "family" (other relatives, such as uncle, aunt, cousin, grandfather, and grandmother) were not found as sources of information and discussion concerning the career choice process for the five categories. In order to identify in which areas these factors show some difference, we analyzed the answers and looked for a tendency in any direction, suggesting a higher or lower influence level. Thus, the factor "mother" had influence for the areas ASS, BS, and O, but it did not influence HS and ES. Beck and Beck-Gernsheim (2002) argue that, in the individualization process, family has been an institution which takes various organization shapes with regard to the individuals' relationships; values and social roles change within the family and a new family culture emerges, less paternalistic, reflecting the second spirit of capitalism.

Therefore, the H1 (the Gen Y sees family as a social institution that exerts less influence on career choice) has not been rejected, since the factor mother influenced on career choice for only two categories, there was no occurrence of the factors family and father.

The H4 (the Gen Y sees Other Significant People as non-influential on the decision to pursue an accounting career) has been rejected. Regarding the factor friends, most individuals have stated to ask for information to and/ or discuss with friends about their professional interests. It has also been found that they ask for information to and/ or discuss with teachers about their professional interests. In S1, women ask for more information to their mothers and less to their friends than men; the opposite has been observed when it comes to teachers. In S2, women ask for more information to their mothers and family and less to their friends and teachers than men.

\subsection{Career Choice Factors}

The comparison among the five categories was conducted using Kruskal-Wallis test (Table 4), due to non-normality of data. In S2, normality has been observed only for the factor prestige. Thus, comparison was conducted using an ANOVA test. Both in S1 and S2, no statistical differences were found for the factors experience and indecision. As for all other factors, there were statistical differences. 
Table 4 Kruskal-Wallis - career choice factors

\begin{tabular}{|c|c|c|c|c|c|c|}
\hline \multirow{3}{*}{ Factors } & \multicolumn{3}{|c|}{ Sample 1} & \multicolumn{3}{|c|}{ Sample 2} \\
\hline & \multicolumn{3}{|c|}{ Kruskal-Wallis } & \multicolumn{3}{|c|}{ Kruskal-Wallis } \\
\hline & $\chi^{2}$ & df & $\begin{array}{c}\text { Asymp. } \\
\text { sign. }\end{array}$ & $\chi^{2}$ & df & $\begin{array}{c}\text { Asymp. } \\
\text { sign. }\end{array}$ \\
\hline Prestige & 14.515 & 4 & 0.006 & - & - & - \\
\hline Social & 157.418 & 4 & 0.000 & 80.698 & 4 & 0.000 \\
\hline Power & 30.288 & 4 & 0.000 & 10.31 & 4 & 0.036 \\
\hline Intrinsic & 19.45 & 4 & 0.001 & 16.176 & 4 & 0.003 \\
\hline Extrinsic & 103.528 & 4 & 0.000 & 65.433 & 4 & 0.000 \\
\hline Experience & 5.009 & 4 & 0.286 & 0.954 & 4 & 0.917 \\
\hline Family & 24.418 & 4 & 0.000 & 12.305 & 4 & 0.015 \\
\hline Indecision & 2.95 & 4 & 0.566 & 6.754 & 4 & 0.149 \\
\hline
\end{tabular}

Source: Prepared by the authors.

The ANOVA results concerning prestige for the five categories (Table 5) showed statistical difference in the influence of this factor on career choice. In order to identify where this difference took place, Tukey's post-hoc test was used (Table 6).

Table 5 ANOVA for career choice factor-prestige

\begin{tabular}{lccccc}
\hline & \multicolumn{5}{c}{ Sample 2 } \\
\hline Prestige & $\begin{array}{c}\text { Sum } \\
\text { of squares }\end{array}$ & df & $\begin{array}{c}\text { Mean } \\
\text { square }\end{array}$ & F & Sig \\
\hline Between groups & 48,836 & 4 & 11.620 & 2.147 & -039 \\
\hline Within groups & $1,658,446$ & 365 & 4.544 & - & - \\
\hline Total & $1,704,925$ & 369 & - & - \\
\hline
\end{tabular}

Source: Prepared by the authors.

Table 6 Tukey test for difference between five categories

\begin{tabular}{|c|c|c|c|c|c|c|c|}
\hline \multirow{2}{*}{$\begin{array}{l}\text { Variable } \\
\text { Prestige }\end{array}$} & \multirow{2}{*}{ Group I } & \multirow{2}{*}{ Group J } & \multirow{2}{*}{$\begin{array}{c}\text { Mean difference } \\
(\mathrm{I}-\mathrm{J})\end{array}$} & \multirow{2}{*}{$\begin{array}{l}\text { Standard } \\
\text { error }\end{array}$} & \multirow{2}{*}{ Sign. } & \multicolumn{2}{|c|}{ Confidence interval $(95 \%)$} \\
\hline & & & & & & lower & upper \\
\hline & ASS & $\mathrm{HS}$ & 0.64275 & 0.32761 & 0.287 & -0.2554 & 1.5409 \\
\hline & ASS & ES & -0.40035 & 0.28050 & 0.610 & -1.1693 & 0.3686 \\
\hline & ASS & BS & -0.00368 & 0.35861 & 1.000 & -0.9868 & 0.9794 \\
\hline & ASS & $\mathrm{O}$ & -0.12065 & 0.50584 & 0.999 & -1.5074 & 1.2661 \\
\hline & $\mathrm{HS}$ & ES & $-1.04310^{*}$ & 0.32709 & 0.013 & -1.9398 & -0.1464 \\
\hline & $\mathrm{HS}$ & BS & -0.64643 & 0.39612 & 0.478 & -1.7324 & 0.4395 \\
\hline & $\mathrm{HS}$ & $\mathrm{O}$ & -0.76340 & 0.53309 & 0.607 & -2.2248 & 0.6980 \\
\hline & ES & BS & 0.39668 & 0.35814 & 0.803 & -0.5851 & 1.3785 \\
\hline & ES & $\mathrm{O}$ & 0.27970 & 0.50551 & 0.981 & -1.1061 & 1.6655 \\
\hline & BS & $\mathrm{O}$ & -0.11697 & 0.55268 & 1.000 & -1.6321 & 1.3982 \\
\hline
\end{tabular}

Note. ASS = Applied Social Sciences; $E S=$ Exact Sciences; BS = Biological Sciences; HS = Human Sciences; O = Others.

Source: Prepared by the authors. 
Tukey test showed that the difference observed in ANOVA for the factor prestige occurred between the categories HS and ES. Therefore, the statistical difference concerning the perception that this factor has some influence on career choice took place between these two categories. Mean values in these categories indicate that answers had a lower average in the HS, thus individuals from this category tend to perceive career prestige as exerting less influence on career choice when compared to the other categories.

Normality test for gender difference determined that S1 and S2 did not have their normality violated by the factors power and prestige. These two factors were analyzed using Student's $t$-test and all other factors underwent MannWhitney $\mathrm{U}$ test.

The Table 7 displays the results for Mann-Whitney U test, which aimed to identify statistical differences in the answers between genders. The results indicate difference for the social $(\mathrm{U}[\mathrm{n}=665]=35,739,500, p<0.05)$ and intrinsic factors $(\mathrm{U}[\mathrm{n}=665]=39,011,500, p<0.05)$ in $\mathrm{S} 1$, and for the social factor $(U[n=370]=14,273,000, p<0.05)$ in $S 2$.

Table 7 Mann-Whitney for gender difference - career choice factors

\begin{tabular}{lcccc}
\hline & \multicolumn{2}{c}{ Sample 1 } & \multicolumn{2}{c}{ Sample 2 } \\
\hline \multirow{2}{*}{ Factors } & \multicolumn{2}{c}{ Mann-Whitney } & \multicolumn{2}{c}{ Mannitney } \\
\cline { 2 - 5 } & Mann-Whitney U & $\begin{array}{c}\text { Asymp. sign. } \\
\text { (2-tailed) }\end{array}$ & $\begin{array}{c}\text { Mann-Whitney } \boldsymbol{U} \\
\text { (2-tailed) }\end{array}$ & $\mathbf{0 . 0 0 6}$ \\
\hline Social & $35,739,500$ & $\mathbf{0 . 0 0 0}$ & $14,273,000$ & 0.139 \\
\hline Intrinsic & $39,011,500$ & $\mathbf{0 . 0 1 5}$ & $15,591,000$ & 0.246 \\
\hline Extrinsic & $42,513,000$ & 0.395 & $15,919,500$ & 0.696 \\
\hline Experience & $43,464,000$ & 0.673 & $16,710,500$ & 0.126 \\
\hline Family & $40,473,000$ & 0.077 & $15,540,500$ & $16,062,500$ \\
\hline Indecision & $43,166,000$ & 0.578 & & 0.307 \\
\hline
\end{tabular}

Source: Prepared by the authors.

Table 8 displays the results for Student's $t$-test concerning differences between genders. Gender-related differences between power and prestige were not observed both for $\mathrm{S} 1$ and S2.

The results indicate that the $\mathbf{H} \mathbf{2}$ (intrinsic factors of the accounting practice are believed to exert less influence on career choice) has been rejected. This hypothesis contradicts what has been observed in the literature, e.g. Ahmed et al. (1997) and Chen et al. (2008), where the authors claims that intrinsic factors do not influence on the decision to pursue an accounting career. The results do not corroborate the analysis of generational characteristics, they show that the Gen Y assign more relevance to values like openness to change and less relevance to values like conservation and tradition. Regarding the category ASS, the results corroborate the generational characteristics under analysis, since intrinsic factors are related to openness to change.

Table 8 Student's t-test for equality of mean values - career choice factors

\begin{tabular}{|c|c|c|c|c|c|c|c|c|}
\hline & & \multicolumn{7}{|c|}{ Sample 1} \\
\hline & & \multicolumn{7}{|c|}{ Student's $t$} \\
\hline \multirow[t]{2}{*}{ Factors } & \multirow[t]{2}{*}{ Variance } & \multirow[t]{2}{*}{$\mathbf{t}$} & \multirow[t]{2}{*}{ df } & \multirow{2}{*}{$\begin{array}{l}\text { Sign. } \\
\text { (2-tailed) }\end{array}$} & \multirow{2}{*}{$\begin{array}{c}\text { Mean } \\
\text { difference }\end{array}$} & \multirow[t]{2}{*}{ Standard error } & \multicolumn{2}{|c|}{$\begin{array}{c}\text { Confidence interval } \\
(95 \%)\end{array}$} \\
\hline & & & & & & & lower & upper \\
\hline \multirow{2}{*}{ Prestige } & Equal variance assumed & -0.425 & 663 & 0.671 & -0.07809 & 0.18385 & -0.43909 & 0.28291 \\
\hline & Unequal variance assumed & -0.433 & 347.605 & 0.665 & -0.07809 & 0.18034 & -0.43279 & 0.27662 \\
\hline \multirow{2}{*}{ Power } & Equal variance assumed & 0.144 & 663 & 0.886 & 0.02138 & 0.14875 & -0.27069 & 0.31345 \\
\hline & Unequal variance assumed & 0.141 & 320.422 & 0.888 & 0.02138 & 0.15193 & -0.27752 & 0.32028 \\
\hline
\end{tabular}


Table 8 Continued

\begin{tabular}{lllcccccc}
\hline & \multicolumn{7}{c}{ Sample 2 } \\
\hline \multirow{3}{*}{ Prestige } & Equal variance assumed & -0.566 & 368 & 0.572 & -0.12659 & 0.22370 & -0.56649 & 0.31330 \\
\cline { 2 - 8 } & Unequal variance assumed & -0.566 & 365.370 & 0.572 & -0.12659 & 0.22370 & -0.56650 & 0.31331 \\
\hline \multirow{2}{*}{ Power } & Equal variance assumed & -0.280 & 368 & 0.780 & -0.05092 & 0.18200 & -0.40880 & 0.30697 \\
\cline { 2 - 7 } & Unequal variance assumed & -0.280 & 367.622 & 0.780 & -0.05092 & 0.18200 & -0.40881 & 0.30697 \\
\hline
\end{tabular}

Source: Prepared by the authors.

a) The $\mathbf{H 3}$ (extrinsic factors exert more influence on career choice) has not been rejected, corroborating Ahmed et al. (1997) and Chen et al. (2008), as these authors demonstrated that market factors influence the Gen Y on career choice. It has been observed in all five categories.

b) The $\mathbf{H 5}$ (the Gen Y does not see accounting as a prestigious career, therefore, this is not an influential factor on career choice) has been rejected. The results indicate that the Gen Y perceives the prestige of a career as exerting influence on its decision to pursue an accounting career; this does not corroborate the findings by Azevedo (2010), as well as our focus group interviews. Power was also regarded as exerting influence on the decision to pursue an accounting career, it is related to the prestige of the profession. c) The $\mathbf{H 6}$ (social factors exert less influence on career choice in accounting in the Gen Y) has not been rejected. Sutherland and Hoover (2007) point out that a characteristic of the Gen $\mathrm{Y}$ is conventionalism. These authors cite studies where around $75 \%$ of individuals from the Gen Y state to advocate values similar to those supported by their parents. The authors claim that, from time to time, these young people tend to come together in order to save the world, showing a concern with social and justice issues. Therefore, the demands pointed out by Boltanski and Chiapello (2009) concerning the job market do not seem to meet people's expectations, although the $\mathbf{H 6}$ has not been rejected in this study, and social factors did not exert influence on career choice for the category ASS.

\section{CONCLUSIONS}

This study aimed to identify which factors and how social institutions influence the Gen $\mathrm{Y}$ to choose accounting as its career. The theoretical framework for this article has been based on Mannheim's Generational Theory, as well as on the literature addressing career choice and on the discussions about the job market, particular concerning the discussions proposed by Boltanski and Chiapello (2009) about the new spirit of capitalism.

Discussions on media and on the academic context concerning the Gen Y have been focusing on job market issues and how the unique characteristics of this generation affect the job market with regard to work organization and workers selection and retention. This is a generation that grew up within a period of economic and technological development, experiencing new ways of interacting with the world, forcing companies to adopt new organization modes to meet people's expectations and demands. Such a new setting affects every one of us, individuals belonging to all generations.

Regarding the Gen Y, it was observed that intrinsic factors of the profession - creativity, autonomy, challenging and dynamic environment - exerted an influence on the career choice process, something which does not corroborate the literature, in previous studies only extrinsic factors were relevant in the decision to pursue an accounting career. The questionnaire aimed to evaluate career choice as a whole and there is no specific questions about accounting career.

Also associated with intrinsic factors, social factors working with people and contributing to society - did not influence on the career choice process in our sample. This finding may represent a bias, because all five categories under analysis consisted of more than one career. For instance, if the category ASS had more candidates for any other career but accounting, there might be a bias towards this group.

Mannheim, in his Generational Theory, discusses the formation of generational units where all members share the same entelechy, therefore they might share a similar way of thinking. This claim may be used to justify data groupings in this study. The results indicate that these individuals, although sharing a similar mentality, experience the same stimuli in different ways, thus they may not belong to the same generational unit. This is a possibility because 
other factors should be taken into account, such as the individuals' cultural background and socialization process. Thus, grouping individuals into the categories proposed has not been effective and the factors mentioned above were underestimated.

This study also indicated less family influence on the career choice process, something which has not been observed in other studies. New types of family structure may explain such a lower influence, there is a fragile relationship between family members, although some of them may influence at an individual level (e.g. father, mother).

Finally, the PVQ, as proposed by Schwartz (1994), aimed to determine accountants' traits and values. This questionnaire indicates that individuals who pursue an accounting career tend to assign less relevance to tradition and they are rather open to new experiences and freedom to take action and make decisions, in addition to seeking fulfillment and happiness. The results for the category ASS may reflect these traits to a certain extent; individuals from this category regard both extrinsic factors - moneymaking, job security, job availability - and intrinsic factors - creativity, autonomy, challenge - as exerting influence on the career choice process. As for the category ASS, the PVQ has suggested that tradition seems to be less relevant than openness to change.

Socialization processes are dynamic and many variables exert an influence on how individuals experience changes in society. This generational unit (i.e. the Brazilian one) may wish for more autonomy, creativity, and flexibility at the workplace, and people still mind about job security and money-making.

Two main contributions may be identified in this research: first, many results differed from previous studies, raising issues of interest for further research; second, this has been the very first research to address the decision to pursue an accounting career with Brazilian High School students. The findings of this study may provide useful information to administrators and faculty members in Higher Education institutions, as well as professional representative bodies and hiring organizations. Those who regard accounting as an exact science can find themselves buying a pig in a poke.

\subsection{Study Limitations}

This study has some limitations to be considered.

First, the sample mostly consists of people from Greater São Paulo, Brazil. Although data has been collected during a public event, this does not allow a generalization of the results.

Second, few individuals had accounting as their career of choice. This does not allow analyzing this group alone, so it has been included in the category ASS, something which does not ensure that all individuals perceive and experience events in a similar way.

And third, the statistical analysis has not provided consistent results. Kruskal-Wallis non-parametric test does not allow identifying differences between groups, contrary to the ANOVA test.

\subsection{Further Studies}

This study aimed to grasp which factors influence the generation $\mathrm{Y}$ to choose accounting as its career before entering Higher Education, based on the literature and focus groups. For further research, we suggest an assessment of students' expectations before starting and after completing the accounting course. This may open up new discussions. Could a stereotypical perception of accounting as an exact science and a methodical practice attract people with traits the job market has not been looking for?

\subsection{Final Remarks}

A stereotypical perception of accounting before and after entering Higher Education may lead individuals to realize that their expectations have not been met, with an increased risk of course dropout and evasion; there is also a possibility of providing Higher Education certificates to accounting practitioners who become unmotivated or do not meet the job market's expectations. These negative outcomes may derive from the Higher Education design, since accounting courses follow a strict curriculum, with few possibilities for innovation, creativity, and autonomy, attaching a negative image to accounting education. Nowadays, it seems like an accounting student wears a scarlet letter " $\mathrm{A}$ " on her/his chest, becoming a $21^{\text {st }}$ century Hester Prynne within the university context. 


\section{References}

Ahmed, K., Alam, K. F., \& Alam, M. (1997). An empirical study of factors affecting accounting student's career choice in New Zealand. Accounting Education, 6(4), 325-335.

Albrecht, W. S., \& Sack, R. J. (2000). Accounting education: charting the course through a perilous future. Accounting Education Series, 16, $1-72$.

Almeida, F. J. R., \& Sobral, F. J. B. A. (2009). O sistema de valores humanos de administradores brasileiros: adaptação da escala de valores PVQ para estudo de valores no Brasil. Revista de Administração Mackenzie, 10(3), 101-126.

Almeida, M. E. G. G., \& Pinho, L. V. (2008). Adolescência, família e escolhas:implicações na orientação profissional. Psicologia Clínica, 20(2), 173-184.

Auyeung, P., \& Sands, J. (1997). Factors influencing accounting students' career choice: a cross cultural validation study. Accounting Education, 6(1), 13-23.

Azevedo, R. F. L. (2010). A percepção pública sobre os contadores: "bem ou mal na foto"? (Master's Degree). Faculdade de Economia, Administração e Contabilidade, Universidade de São Paulo, São Paulo.

Barreto, M. A., \& Aiello-Vaisberg, T. (2007). Escolha profissional e dramática do viver adolescente. Psciologia \& Sociedade, 19(1), 107114.

Beck, U., \& Beck-Gernsheim, E. (2002). Individualization: institutionalized individualism and its social and political consequences. London, England: SAGE.

Bengtson, V. L., Furlong, M. J., \& Laufer, R. S. (1983). Time, aging, and the continuity of social structure: themes and issues in generational analysis. Journal of Social Issues, 39(4), 45-71.

Boltanski, L., \& Chiapello, È. (2009). O novo espírito do capitalismo. São Paulo, SP: Martins Fontes.

Cavazotte, F. S. C. N., Lemos, A. H. C., \& Viana, M. D. A. (2012), Novas gerações no mercado de trabalho: expectativas renovadas ou antigos ideais? Cadernos EBAPE.BR, 10(1), 162-180.

Chen, C., Jones, K. T., \& McIntyre, D. D. (2008). Analyzing the factors relevant to student's estimations of the benefits and costs of pursuing an accounting career. Accounting Education: An International Journal, 17(3), 313-326.

Cronbach, L. J. (1951). Coefficient alpha and the internal structure of tests. Psychometrika, 16(3), 297-334.

Danziger, N., \& Eden, Y. (2006). Student career aspirations and perceptions: the case of Israeli accounting students. Accounting Education: An International Journal, 15(2), 113-134.

Dejoux, C., \& Wechtler, H. (2011). Diversité générationnelle: implications, principes et outils de management. Revue Management \& Avenir, 3(43), 227-238.

Dubar, C. (2005). A socialização: construção das identidades sociais e profissionais. São Paulo, SP: Martins Fontes.

Eisner, S. P. (2005). Managing generation Y. SAM Advanced Management Journal, 70, 4-12.

Fávero, L. P., Belfiore, P., Silva, F. L., \& Chan, B. L. (2009). Análise de dados: modelagem multivariada para tomada de decisões. Rio de Janeiro, RJ: Elsevier Editora Ltda.

Gati, I., Krausz, M., \& Osipow, S. H. (1996). A taxonomy of difficulties in career decision making. Journal of Counseling Psychology, 43(4), 510-526.

Gati, I., Saka, N. (2001). High school students' career-related decisionmaking difficulties. Journal of Counseling \& Development; 79.(3), 331-340.

Germeijs, V., \& Verschueren, K. (2006). High school students' career decision-making process: development and validation of the Study Choice Task Inventory. Journal of Career Assessment, 14(4), 449-471.

Gras, N. S. B. (1942). Capitalism: concepts and history. Bulletin of the Business Historical Society, 16(2), 21-42.

Hickel, J., \& Khan, A. (2012). The culture of capitalism and the crisis of critique. Anthropological Quaterly, 85(1), 203-228.
Hirschi, A., \& Läge, D. (2007). The relation of secondary student's career-choice readiness to a six-phase mode of career decision making. Journal of Career Development, 34(2), 164-191.

Laufer, R. S., \& Bengston, V. L. (1974). Generations, aging, and social stratification: on the development of generational units. Journal of Social Issues, 30(3), 181-205.

Lindquist, T. M. (2008). Recruiting the millennium generation: the new CPA. The CPA Journal, 78(8), 56.

Lipovetsky, G. (2011). Os tempos hipermodernos. São Paulo, SP: Barcarolla.

Mannheim, K. (1952). The problem of generations. In K. Mannheim, Essays on the sociology of knowledge (pp. 297-312). New York, NY: Oxford University Press.

Mauldin, S., Crain, J. L., \& Mounce, P. H. (2000). The accounting principles instructor's influence on student's decision to major in accounting. Journal of Education for Business, 75(3), 142-148.

Milliron, V. C. (2008). Exploring millennial student values and societal trends: accounting course selection preferences. Issues in Accounting Education, 23(3), 405-419.

Mirador Internacional. (1977). Dicionário brasileiro da língua portuguesa. (2a. ed.). São Paulo, SP: Encyclopaedia Britannica do Brasil Publicações Ltda.

Nepomuceno, R. F., \& Witter, G. P. (2010). Influência da família na decisão profissional: opinião de adolescentes. Revista Semestral da Associação Brasileira de Psicologia Escolar e Educacional, 14(1), 15-22:

Ojeda,-B. S., Creutzberg, M., Feoli, A. M. P., Melo, D. S., \& Corbellini, V. L. (2009). Acadêmicos de enfermagem, nutrição e fisioterapia: a escolha profissional. Revista Latino-Americana de Enfermagem, 17(3), 396-402.

Oliveira, M. D. A., \& Melo-Silva, L. L. (2010). Estudantes universitários: a influência das variáveis socioeconômicas e culturais na carreira. Revista Semestral da Associação Brasileira de Psicologia Escolar é Educacional, 14(1), 23-34.

Oliveira, S. R., Piccinini, V. C., \& Bitencourt, B. M. (2012). Juventude, gerações e trabalho: é posșível falar em geração Y no Brasil? Organizações \& Sociedade, 19(62), 551-558.

Pereira, F. N., \& Garcia, A. (2007). Amizade e escolha profissional: influência ou cooperação? Revista Brasileira de Orientação Profissional, 8(1), 71-86.

Pimenta, M. M. (2007). "Ser jovem" e "ser adulto": identidades, representações e trajetórias (Doctoral Thesis). Faculdade de Filosofia Letras e Ciências Humanas, Universidade de São Paulo, São Paulo.

Santos, L. M. M. (2005). O papel da família e dos pares na escolha professional. Psicologia em Estudo, 10(1), 57-66.

Scharf, E. R., Rosa, C. P., \& Oliveira, D. (2012). Os hábitos de consumo das gerações $\mathrm{Y}$ e Z: a dimensão ambiental nos contextos familiar e escolar. Revista Contemporânea de Economia e Gestão, 10(1), 48-60.

Schwartz, S. H. (1994). Are there universal aspects in the structure and contents of human values? Journal of Social Issues, 50(4), 19-45.

Schwartz, S: H. (n.d). Computing scores for the 10 human values. Retrieved from http://ess.nsd.uib.no/ess/doc/ess1_human_values_ scale.pdf

Schwartz, S. H., Bardi, A. (2001). Values hierarchies across cultures: taking a similarities perspective. Journal of Cross-Cultural Psychology, 32(3), 268-290.

Schwartz, S. H., Gila, M., Lehmann, A., Burgess, S., Harris, M., \& Owens, V. (2001) Extending cross-cultural validity of the theory of human values with a different method of measurement. Journal of CrossCultural Psychology, 32(5), 519-542.

Smith, M. (2012). Research methods in accounting. London, England: SAGE.

Stein, J. (2013, May). The new greatest generation: why Millennials will save us all. Time Magazine, 181(19), 28-35.

Sugahara, S., Boland, G., \& Cilloni, A. (2008). Factors influencing students' choice of an accounting major in Australia. Accounting Education: An International Journal, 17(Suppl 1), 37-54. 
Sugahara, S., Kurihara, O., \& Boland, G. (2006). Japanese secondary school teachers' perceptions of the accounting profession. Accounting Education: An International Journal, 15(4), 405-418.

Sutherland, T., \& Hoover, G. (2007). The Millennials: who are these students staring back at you in the classroom? Accounting Education News, 35(3), 5-6.
Tan, L. M., \& Laswad, F. (2006). Student's beliefs, attitudes and intentions to major in accounting. Accounting Education: An International Journal, 15(2), 167-187.

Vasconcelos, K. C. A., Merhi, D. Q., Goulart, V. M., \& Silva, A. R. L. (2010). A geração Y e suas âncoras de carreira. Revista Eletrônica de Gestão Organizacional, 8(2), 226-244.

\section{Correspondence address:}

\section{Jony Hsiao}

Universidade de São Paulo, Faculdade de Economia, Administração e Contabilidade Avenida Professor Luciano Gualberto 908, Prédio FEA 3, Sala 105c - CEP: 05508-010 Cidade Universitária - São Paulo - SP - Brazil

Email: jony.hsiao@usp.br 